\title{
Upregulation of Death Receptor 5 and Production of Reactive Oxygen Species Mediate Sensitization of PC-3 Prostate Cancer Cells to TRAIL Induced Apoptosis by Vitisin $\mathrm{A}$
}

\author{
Deokil Shin ${ }^{b}$ Hee-Young Kwon ${ }^{a}$ Eun Jung Sohn ${ }^{a}$ Moon Sik Nam ${ }^{b}$ Jung Hyo \\ Kim $^{c}$ Jae Chul Lee ${ }^{b}$ Shi-Yong Ryu ${ }^{d}$ Byungchun Park ${ }^{a}$ Sung-Hoon Kim ${ }^{a}$ \\ aCollege of Korean Medicine, Kyung Hee University, Seoul, bGraduate School of East-West Medical \\ Science, Kyung Hee University, Yongin, 'Chosun Nursing College, Gwangju, South Korea \\ ${ }^{d}$ Korea Research Institute of Chemical Technology, Daejeon, South Korea
}

\section{Key Words}

Vitisin A • DR5 • TRAIL • Apoptosis $・$ ROS $・$ PC-3 cells

\begin{abstract}
Background/Aims: Although Vitisin A, derived from wine grapes, is known to have cytotoxic, anti-adipogenic, anti-inflammatory and antioxidant effects, the underlying antitumor mechanism has not been investigated in prostate cancer cells to date. In the present study, the apoptotic mechanism of Vitisin A plus TNF-related apoptosis-inducing ligand (TRAIL) in prostate cancer cells was elucidated. Methods: The cytotoxicity of Vitisin A and/or TRAIL against PC-3, DU145 and LNCaP prostate cancer cells was measured by MTT colorimetric assay. Annexin V-FITC Apoptosis Detection kit was used to detect apoptotic cells by flow cytometry. Intracellular levels of ROS were measured by flow cytometry using 2070-diacetyl dichlorofluorescein (DCFDA). Results: Combined treatment with Vitisin A and TRAIL enhanced cytotoxicity and also increased sub-G1 population in PC-3 cells better than DU145 or LNCap prostate cancer cells. Similarly, Annexin V and PI staining revealed that combination increased early and late apoptosis in PC-3 cells compared to untreated control. Consistently, combination attenuated the expression of pro-caspases $7 / 8, \mathrm{DcR} 1, \mathrm{Bcl}-\mathrm{XL}$ or Bcl-2 and activated caspase 3, FADD, DR5 and DR4 in PC-3 cells. Also, combination increased DR5 promoter activity compared to untreated control. Furthermore, combination increased the production of reactive oxygen species (ROS) and DR5 cell surface expression. The ROS inhibitor NAC and silencing of DR5 by siRNA transfection inhibited the ability of combination to induce PARP cleavage and generate ROS. Conclusion: These findings provide evidence that Vitisin A can be used in conjunction with TRAIL as a potent TRAIL sensitizer for synergistic apoptosis induction via upregulation of DR5 and production of ROS in prostate cancer cells.

D. Shin, H.-Y. Kwon and E.J. Sohn equally contributed to this study.

Sung-Hoon Kim

Cancer Preventive Material Development Research Center, College of Korean Medicine, Kyung Hee University, 1 Hoegi-dong, Dongdaemun-gu, Seoul 130-701, (South Korea) Tel. +82-2-961-9233; Fax +82-2-964-1074, E-Mail sungkim7@khu.ac.kr
\end{abstract}

KARGER 125 


\begin{tabular}{|c|c|c|}
\hline Cellular Physiology & Cell Physiol Biochem 2015;36:1151-1162 & \\
\hline and Biochemistry & $\begin{array}{l}\text { Dol: } 10.1159 / 000430286 \\
\text { Published online: June 25, } 2015\end{array}$ & $\begin{array}{l}\text { (0) } 2015 \text { S. Karger AG, Basel } \\
\text { www.karger.com/cpb }\end{array}$ \\
\hline
\end{tabular}

\section{Introduction}

Prostate cancer is the most common cancer in males worldwide [1]. Current medical treatment approaches include surgery, chemotherapy, radiation therapy, hormonal therapy, cryosurgery and high-intensity focused ultrasound [2]. It was well documented that TNFrelated apoptosis-inducing ligand (TRAIL/Apo2L) has been used to induce in several cancers [3-6]. TRAIL-induced apoptosis pathway is similar to TNF and Fas death receptor pathways including the binding of Fas-associated-death domain (FADD) proteins leading to activation of apoptotic cell death. TRAIL receptors R1, R2, R3 and R4 are known as DR4, DR5, DcR1, and DcR2, respectively [7].

Though TRAIL is a promising anticancer agent, TRAIL resistance is a major barrier to effective cancer therapy [8]. Notably, prostate cancer cells such as CWR22Rv1, DU145, DuPro, JCA- 1, LNCaP, PC-3, PPC-1 and PrEC cells are resistant to $100 \mathrm{ng} / \mathrm{ml}$ TRAIL-induced apoptosis $[9,10]$. Thus, TRAIL sensitizers from natural sources such as trichostatin A [11], curcumin [12], sulforaphane [13], zyflamend [14] and cardamonin [15] are considered attractive with low toxicity and less resistance in normal cells.

Vitisin A [16], a complex of resveratrol dimers found in grapes and red wine, is known to have anti-inflammatory effects on RAW 264.7 cells by inhibiting ERK, p38, and NF-kappaB activation [17], cytotoxic effects on human leukemia cells [18], anti-migratory activity [19], anti-adipogenic effects on 3T3-L1 cells [20], and anti-viral activity in A549 alveolar epithelial cells through interference with Akt and STAT1 phosphorylation [21]. Nevertheless, the underlying apoptotic mechanism of Vitisin A in prostate cancer cells has not been clearly elucidated. Thus, in the present study, the potential of Vitisin A to sensitize PC-3 prostate cancer cells to TRAIL-mediated apoptosis was evaluated by MTT assay, cell cycle analysis, Western blotting, flow cytometric analysis of ROS, and DR5 small interfering RNA (siRNA) transfection assay.

\section{Materials and Methods}

\section{Cell culture}

PC-3, DU 145 and LNCaP prostate cancer cells were obtained from the American Type Culture Collection (ATCC, Manassas, VA, USA). The cells were cultured in RPMI 1640 (Welgene, New York, USA) supplemented with $10 \%$ fetal bovine serum (FBS) (Welgene, New York, USA) and $1 \%$ penicillin-streptomycin (Invitrogen, Carlsbad, CA, USA) at $37^{\circ} \mathrm{C}$ in a humidified $5 \% \mathrm{CO}_{2}$ atmosphere. Vitisin A (purity $>95 \%$ ) was obtained from Dr. Shi-Yong Ryu from the Korean Research Institute of Chemical Technology (Daejon, Korea).

\section{Cytotoxicity assay}

The cytotoxicity of Vitisin A (4 or $8 \mu \mathrm{M}$ ) (Fig. 1A) and/or TRAIL (20 or 40 ng/ml) (Sigma, St. Louis, M0, USA) against PC-3, DU145 and LNCaP prostate cancer cells in 96-well microplates was measured by MTT colorimetric assay. The prostate cancer cells were seeded onto 96-well microplates at a density of $1 \times 10^{4}$ cells per well and treated with various concentrations of Vitisin A and/or TRAIL for $24 \mathrm{~h}$. MTT working solution $\left(5 \mathrm{mg} / \mathrm{ml}\right.$ in PBS) was added to each well and the plates were incubated at $37^{\circ} \mathrm{C}$ for $2 \mathrm{~h}$. The optical density (OD) was then measured at $570 \mathrm{~nm}$ using a Sunrise microplate reader (TECAN, Männedorf, Switzerland). Cell viability was calculated as the percentage of viable cells treated with Vitisin A and/or TRAIL versus untreated control cells using the following equation: Cell viability (\%) = [OD (Treatment) - OD (Blank)] / [OD (Control) - OD (Blank)] × 100 .

\section{Cell cycle analysis}

PC-3, DU145 and LNCaP cells $\left(2.5 \times 10^{5}\right)$ treated with Vitisin A (4 or $\left.8 \mu \mathrm{M}\right)$ and/or TRAIL (20 or 40 $\mathrm{ng} / \mathrm{ml}$ ) for $24 \mathrm{~h}$ were fixed in $75 \%$ ethanol at $-20^{\circ} \mathrm{C}$, resuspended in PBS containing RNase A (1 mg/ml) and incubated for $1 \mathrm{~h}$ at $37^{\circ} \mathrm{C}$. The fixed cells were stained with propidium iodide (PI; $50 \mu \mathrm{g} / \mathrm{ml}$ ) for 30 min at room temperature in the dark. The DNA contents of the stained cells were analyzed using the CellQuest Software with a FACSCalibur flow cytometer (Becton Dickinson, Franklin Lakes, NJ). 


\section{Cellular Physiology Cell Physiol Biochem 2015;36:1151-1162 \begin{tabular}{ll|l} 
and Biochemistry & $\begin{array}{l}\text { DOI 10.1159/000430286 } \\
\text { Published online: June 25, } 2015\end{array}$ & $\begin{array}{l}\text { O 2015 S. Karger AG, Basel } \\
\text { www.karger.com/cpb }\end{array}$ \\
\cline { 2 - 3 }
\end{tabular} \\ Shin et al: Combination of TRAIL and Vitisin A Synergistically Induces Apoptosis}

Apoptosis using flow cytometry with Annexin V and PI staining

Annexin V-FITC Apoptosis Detection kit (BioVision, CA, USA) was used to detect apoptotic cells by flow cytometry according to the manufacturer's instructions. Cells were trypsinized and pelleted by centrifugation at 1,000 rpm for $5 \mathrm{~min}$. The pellets were then resuspended in binding buffer (500 $\mu \mathrm{l})$, added $5 \mu \mathrm{l}$ of Annexin V-FITC and $5 \mu \mathrm{l}$ of propidium iodide $(50 \mu \mathrm{g} / \mathrm{ml})$ and incubated at room temperature for 5 min in the dark. Fluorescence intensity was measured by FACS Calibur flow cytometer and analyzed using the CellQuest Pro data analysis software.

\section{Western blotting}

Cells $\left(2.5 \times 10^{5}\right)$ exposed to Vitisin A $(4 \mu \mathrm{M})$ and/or TRAIL $(20 \mathrm{ng} / \mathrm{ml})$ for $24 \mathrm{~h}$ were washed with cold PBS and centrifuged. The cells were incubated with RIPA buffer (50 mM Tris- $\mathrm{HCl}$ [pH 7.5], $150 \mathrm{mM}$ sodium chloride, $1 \%$ Triton X-100, $0.1 \%$ SDS, 2 mM EDTA, $0.5 \%$ sodium deoxycholate) on ice for $30 \mathrm{~min}$ at $4{ }^{\circ} \mathrm{C}$ and then centrifuged at $14,000 \mathrm{~g}$ for $30 \mathrm{~min}$ at $4^{\circ} \mathrm{C}$. The protein contents of the supernatants were measured using a DC Protein Assay Kit II (Bio-Rad, Hercules, CA, USA). The proteins were then separated on 4-12\% NuPAGE Bis-Tris gels (Invitrogen, New York, USA) and electro-transferred onto Hybond ECL transfer membranes (GE Healthcare Bio-Sciences, Piscataway, NJ,USA). The membranes were blocked with 5\% nonfat dry milk and immunoblotted with antibodies against caspase 3 , cleaved caspase 3 , caspase 7 , cleaved caspase 7 , caspase 8, PARP, Bcl-2, Bcl- $\mathrm{x}_{\mathrm{L}}$, DR4, DR5, FADD, DcR1 and $\beta$-actin (Cell Signaling, Danvers, MA,USA).

Measurement of reactive oxygen species (ROS) production by flow cytometry and using a microplate fluorometer

PC-3 cells $\left(2.5 \times 10^{5}\right)$ were cultured in a 96-well cell culture plate and then pre-incubated with DCFHDA for $1 \mathrm{~h}$ at $37^{\circ} \mathrm{C}$. After incubation, DCFH-DA-loaded cells were treated with Vitisin A ( $\left.4 \mu \mathrm{M}\right)$ and/or TRAIL $(20 \mathrm{ng} / \mathrm{ml})$ for $1 \mathrm{~h}$ at $37^{\circ} \mathrm{C}$. Intracellular levels of ROS were measured by flow cytometry using 2070-diacetyl dichlorofluorescein (DCFDA). ROS production was analyzed using the CellQuest Software with a FACSCalibur flow cytometer. Also, the concentration of DCF was quantified using the OxiSelect Intracellular ROS Assay Kit (Cell Biolabs, CA, USA) and a Fluoroskan Ascent microplate fluorometer (Thomas Scientific, NJ, USA).

Measurement of DR5 cell surface expression by flow cytometry

To detect DR5 cell surface expression, PC-3 $\left(2.5 \times 10^{5}\right)$ cells exposed to TRAIL $(20 \mathrm{ng} / \mathrm{ml})$ and/or Vitisin A $(4 \mu \mathrm{M})$ for $24 \mathrm{~h}$ were incubated with anti-DR5-FITC and anti-mouse IgG antibodies (Abcam, United Kingdom) for $30 \mathrm{~min}$ at room temperature. The stained cells were analyzed using the CellQuest Software with the FACSCalibur flow cytometer.

\section{DR5 small interfering RNA transfection}

PC-3 cells were transiently transfected with a validated scrambled control siRNA vector or a DR5

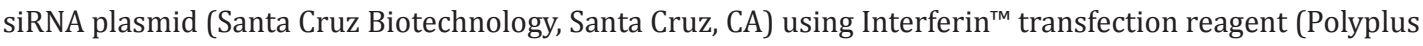
Transfection Inc., New York, NY, USA). Briefly, the mixture of siRNA and Interferin transfection reagent was incubated for $10 \mathrm{~min}$, added to each well containing cells (final siRNA concentration $=40 \mathrm{nM}$ ) and incubated at $37^{\circ} \mathrm{C}$ for $24 \mathrm{~h}$ before Vitisin $\mathrm{A}(4 \mu \mathrm{M})$ and TRAIL $(20 \mathrm{ng} / \mathrm{ml})$ treatment.

\section{DR5 promoter assay}

The pDR5/-605 promoter construct (a gift from Dr. TK Kwon, Keimyung University, Korea) was transfected into PC-3 cells along with a Renilla luciferase reporter plasmid. One day after transfection, cells were treated with Vitisin A ( $4 \mu \mathrm{M})$ and/or TRAIL $(20 \mathrm{ng} / \mathrm{ml})$ for $24 \mathrm{~h}$. Luciferase activity was measured using the Dual-Luciferase Reporter Assay System (Promega, Madison, WI, USA).

Statistical analyses

Statistical analyses were conducted using SigmaPlot version 12 (Systat Software Inc., San Jose, CA, USA). All data are expressed as means \pm standard deviation (SD). Statistically significant differences between treatments and the control were identified by Student's $t$-test. 
Fig. 1. Cytotoxicity of the combination of Vitisin A and TRAIL in prostate cancer cells. Three human prostate cancer cell lines, PC-3, DU145 and LNCap cells, were seeded at a density of $1 \times$ $10^{4}$ cells/well and treated with various concentrations of Vitisin $\mathrm{A}$ $(0,4$ or $8 \mu \mathrm{M})$ and/or TRAIL (20 or $40 \mathrm{ng} / \mathrm{ml}$ ) for $24 \mathrm{~h}$. Cell viability was determined by MTT assay. (A) Chemical structure of Vitisin A. (B) The cytotoxic effects of Vitisin A (4 or $8 \mu \mathrm{M}$ ) and TRAIL (20 or $40 \mathrm{ng}$ / $\mathrm{ml}$ ) on PC-3, DU145 and LNCap prostate cancer cells. Data are presented as means \pm SD of triplicate samples. ${ }^{* * *} \mathrm{p}<0.001$ vs. untreated control in PC-3; \#\# $\mathrm{p}<0.01$,\#\# $\mathrm{p}<0.01$ vs untreated control in PC-3 and DU145 cells.
(A)

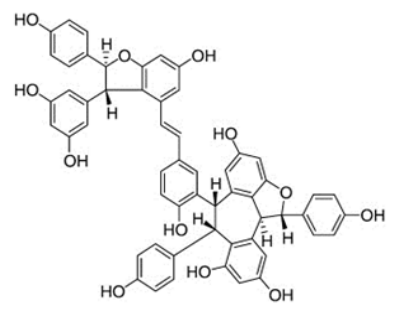

(B)

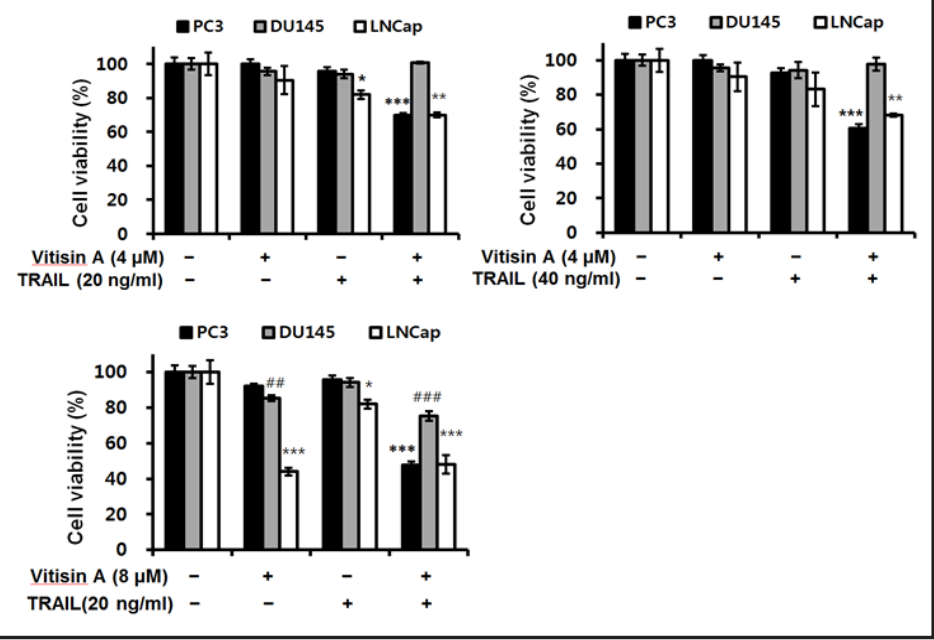

\section{Results}

Combined treatment with Vitisin A and TRAIL enhanced cytotoxicity in PC-3 and DU145 prostate cancer cells

The cytotoxicity of Vitisin A in PC-3, DU145 and LNCaP prostate cancer cells was evaluated by MTT assay. As shown in Fig. 1B, combined treatment with Vitisin A (4 or $8 \mu \mathrm{M})$ and TRAIL (20 or $40 \mathrm{ng} / \mathrm{ml}$ ) for $24 \mathrm{~h}$ showed significantly cytotoxicity in PC-3 and LNCaP prostate cancer cells better than in DU145 cells compared to treatment with Vitisin A or TRAIL alone (Fig.1 B).

Combined treatment with Vitisin A and TRAIL significantly increased the sub-G1 population in $P C-3, D U 145$ and LNCaP prostate cancer cells

To confirm whether the cytotoxicity of combined treatment with Vitisin A and TRAIL was due to apoptosis, cell cycle analysis was carried out in PC-3, DU145 and LNCaP prostate cancer cells. As shown in Fig. 2 A and B , combined treatment of Vitisin A ( $4 \mu \mathrm{M} ; \mathrm{V} 4)$ and TRAIL ( $20 \mathrm{ng} / \mathrm{ml}$;T20) for $24 \mathrm{~h}$ significantly increased the sub-G1 population (to $21.6 \pm 0.1 \%$ ) in PC-3 cells compared to treatment with Vitisin A ( $4 \mu \mathrm{M} ; 1.7 \pm 0.1 \%)$ or TRAIL $(20 \mathrm{ng} / \mathrm{ml}$; $4.6 \pm 0.2 \%$ ) alone. Combined treatment with $4 \mu \mathrm{M}$ Vitisin A and $40 \mathrm{ng} / \mathrm{ml}$ TRAIL (V4T40) significantly increased the sub-G1 population (to $21.9 \pm 1.4 \%$ ) in PC-3 cells compared to treatment with Vitisin A ( $4 \mu \mathrm{M} ; 1.7 \pm 0.1 \%)$ or TRAIL ( $40 \mathrm{ng} / \mathrm{ml} ; 10.0 \pm 0.6 \%)$ alone. Similarly, combined treatment with $8 \mu \mathrm{M}$ Vitisin A and $20 \mathrm{ng} / \mathrm{ml}$ TRAIL (V8T20) significantly increased the sub-G1 population (to $28.7 \pm 0.4 \%$ ) in PC-3 cells compared to treatment with Vitisin A (8 $\mu \mathrm{M} ; 2.7 \pm 0.2 \%$ ) or TRAIL $(20 \mathrm{ng} / \mathrm{ml} ; 4.6 \pm 0.2 \%$ ) alone. Consistently, combined treatment of Vitisin A ( $4 \mu \mathrm{M} ; \mathrm{V} 4)$ and TRAIL (20 ng/ml;T20) for $24 \mathrm{~h}$ significantly increased the early and late apoptosis to $2.85 \pm 2.01 \%$, and $18.24 \pm 1.01 \%$, respectively, in PC-3 cells compared to Vitisin A $(4 \mu \mathrm{M} ; 1.57 \pm 1.19 \%$ and $4.31 \pm 0.46 \%)$ or TRAIL $(20 \mathrm{ng} / \mathrm{ml} ; 2.01 \pm 0.23 \%$ and $5.87 \pm 0.48 \%$ ) alone by Annexin V and PI staining (Fig. 2 C and D). Furthermore, combined 
(A)
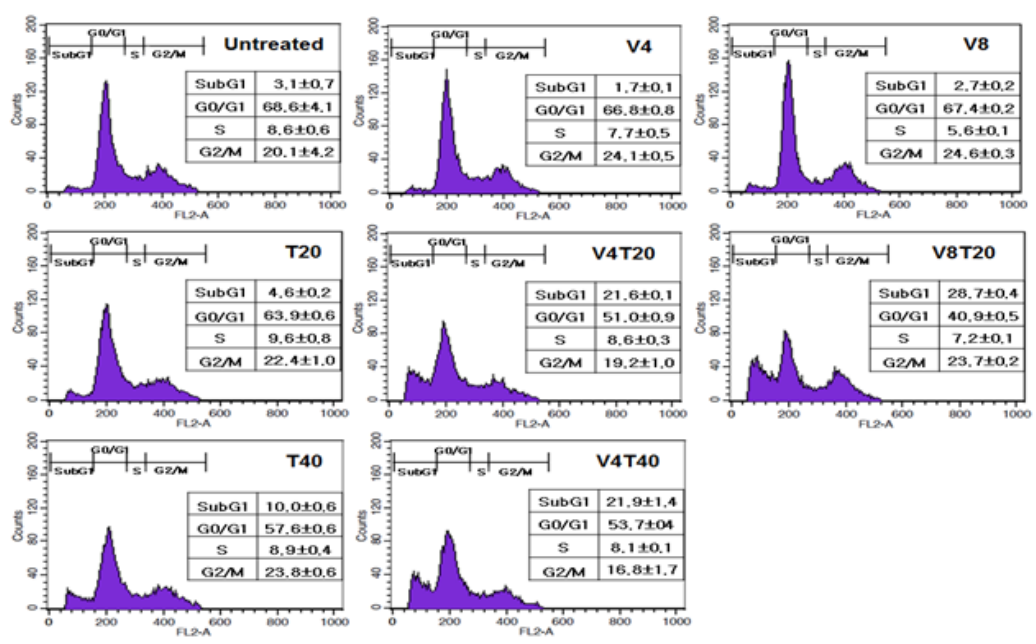

(B)
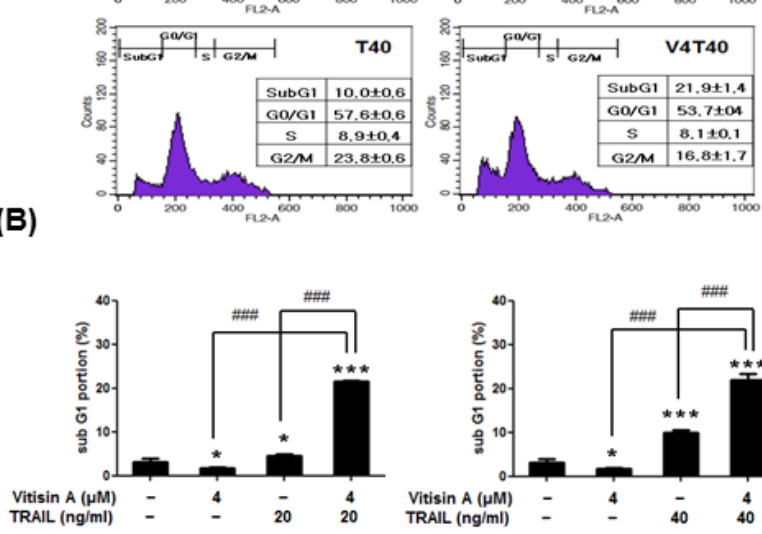

(C)

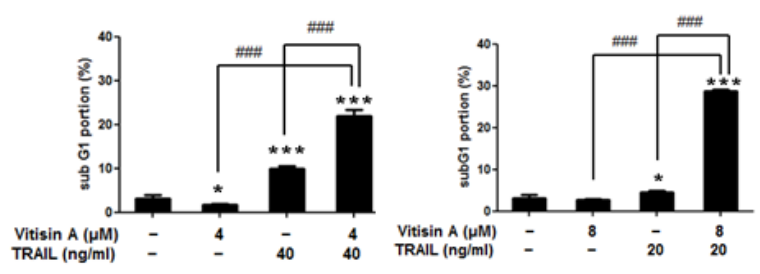

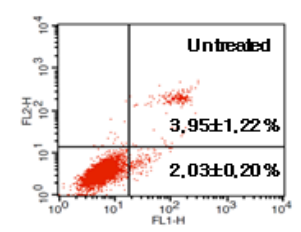

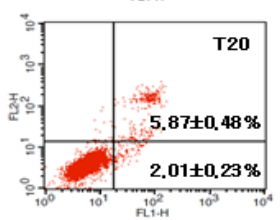

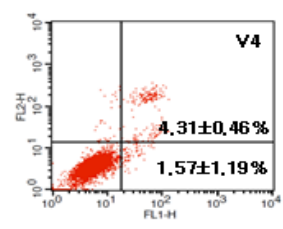

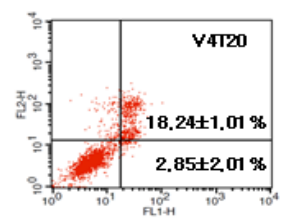

(D)

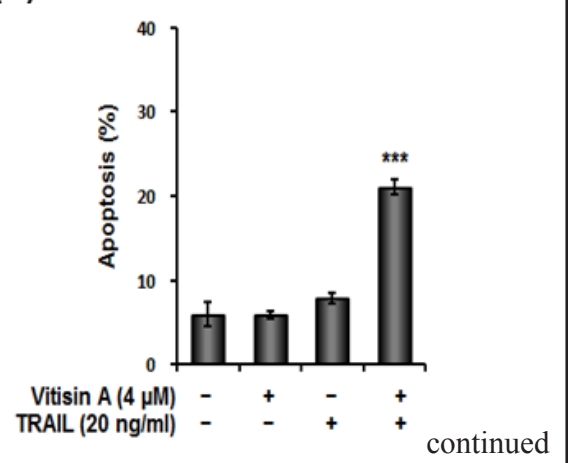

Fig. 2. Combined effect of Vitisin A and TRAIL on the sub-G1 population in PC-3 and DU145 prostate cancer cells. (A) Effects of Vitisin A and TRAIL on the sub-G1 population in PC-3 prostate cancer cells, as shown by FACS cell cycle analysis. PC-3 cells were treated with Vitisin A (4 or $8 \mu \mathrm{M})$ and/or TRAIL (20 or $40 \mathrm{ng} / \mathrm{ml})$ for 24 h. (B) Graph represents sub-G1 population induced by combination of Vitisin A and TRAIL by FACS analysis. (C) Cell death was detected using Annexin V/PI staining by FACS analysis. V4, Vitisin A $4 \mu$ M; V8, Vitisin A $8 \mu \mathrm{M}$; T20, TRAIL $20 \mathrm{ng} / \mathrm{ml}$; V4T20, Vitisin A $4 \mu \mathrm{M}$ and TRAIL $20 \mathrm{ng} / \mathrm{ml}$; V4T40, Vitisin A $4 \mu \mathrm{M}$ and TRAIL $40 \mathrm{ng} / \mathrm{ml}^{*}{ }^{*} \mathrm{p}<0.05,{ }^{* *} \mathrm{p}<0.01{ }^{* * *} \mathrm{p}<0.001$ vs. untreated control; \# $\mathrm{p}<0.05$, \#\# $\mathrm{p}<0.01$, \#\#\# $\mathrm{p}<0.01$ vs. Vitisin A or TRAIL alone. PC-3 cells were stained with Annexin V -FITC and propidium iodide (PI) after treatment with Vitisin A and/or TRAIL. Percentages represent Annexin V-positive/PI-negative (early apoptotic; lower-right quadrant) and Annexin V-positive/PI-positive cells (apoptotic; upper-right quadrant). (D) Graph represents apoptotic portion quantified by AnnexinV/PI staining method. Data are presented as means \pm SD of triplicate samples. ${ }^{* * *} \mathrm{p}<0.001 v s$ untreated control. Effects of Vitisin A and TRAIL on the sub-G1 population in DU145 (E, F) and LNCap (G, H) prostate cancer cells by FACS analysis. DU145, LNCap cells were treated with Vitisin A $(4 \mu \mathrm{M})$ and/or TRAIL $(20 \mathrm{ng} / \mathrm{ml})$ for $24 \mathrm{~h}$ and FACS analysis was carried out. Graph represents sub-G1 phase quantified by FACS analysis. , ${ }^{* *} \mathrm{p}<0.01{ }^{* * *} \mathrm{p}<0.001$ vs. untreated control;\#\#\# p<0.01 vs Vitisin A or TRAIL alone.

treatment of Vitisin A ( $4 \mu \mathrm{M} ; \mathrm{V} 4)$ and TRAIL (20 ng/ml;T20) for $24 \mathrm{~h}$ significantly increased the sub-G1 population (to $10.03 \pm 0.2 \%$ ) in DU145 cells compared to treatment with Vitisin 
(E)
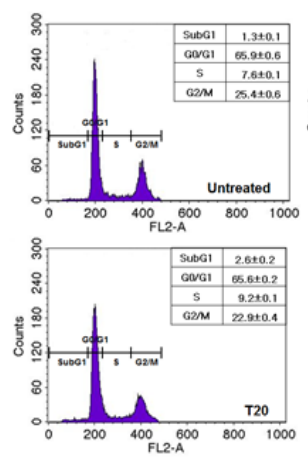

(G)
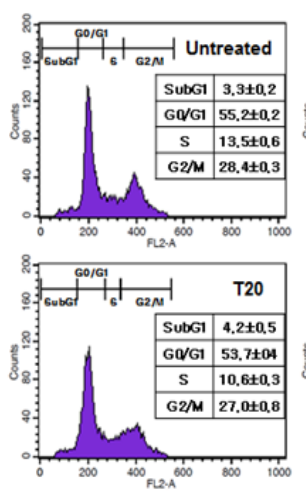

$(\mathbf{F})$
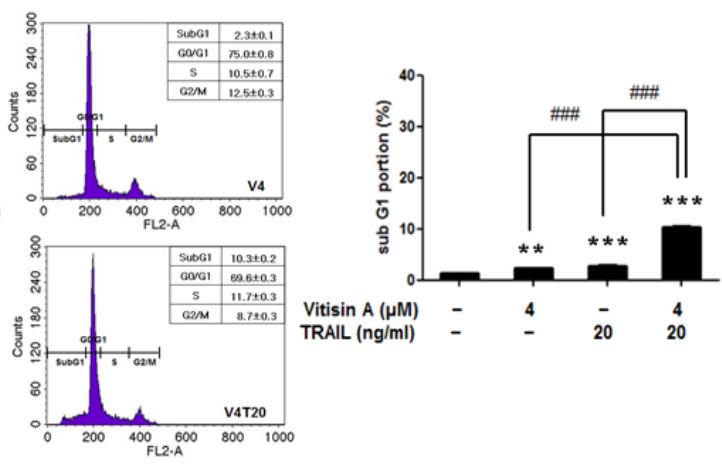

(H)
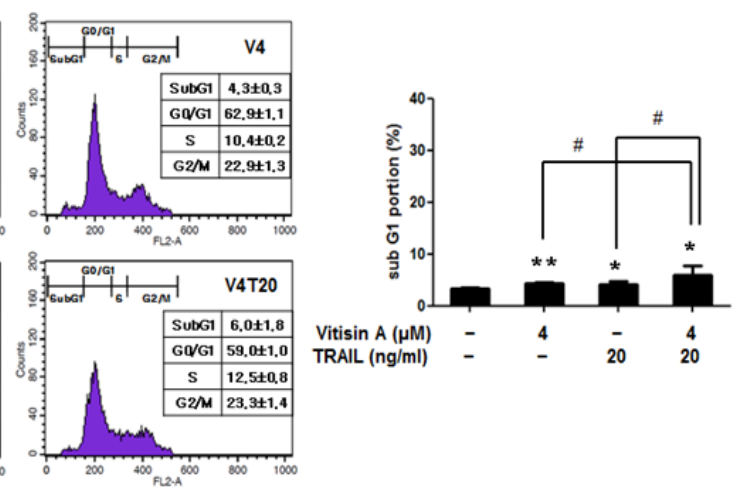

Fig. 3. Combined effect of Vitisin A and TRAIL on pro-apoptotic and survival proteins in PC-3 prostate cancer cells. PC-3 cells were treated with Vitisin A $(4 \mu \mathrm{M})$ and/or TRAIL (20 ng/ml) for $24 \mathrm{~h}$. (A) Effect of Vitisin A and TRAIL on the pro-apoptotic proteins in PC-3 cells. Whole cell extracts were lysed and analyzed by western blotting using antibodies against PARP, pro-caspase $3 / 7 / 8$ and 9 , and cleaved caspse $3 / 7$ or $\beta$-actin. (B) Effect of Vitisin $A$ and TRAIL on the survival proteins in PC-3 cells. Whole cell extracts were lysed and analyzed by western blotting using antibodies against Bcl-xL, Bcl-2 or $\beta$-actin. The values represent the quantified bands of western blots analyzed by using Image J software.
(A)

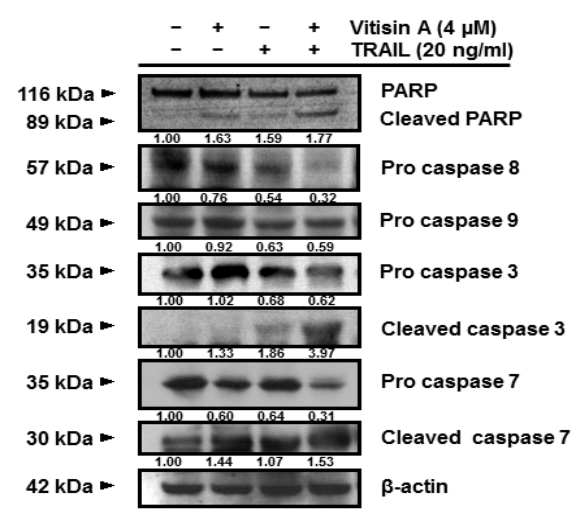

(B)

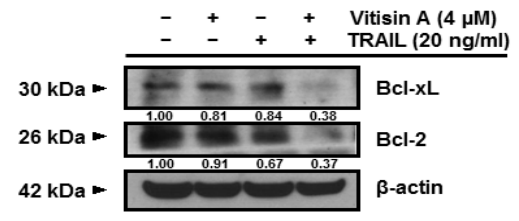

A ( $4 \mu \mathrm{M} ; 2.3 \pm 0.1 \%)$ or TRAIL ( $20 \mathrm{ng} / \mathrm{ml} ; 2.6 \pm 0.2 \%$ ) alone (Fig $2 \mathrm{E}$ and F). Also, combined treatment of Vitisin A ( $4 \mu \mathrm{M} ; \mathrm{V} 4)$ and TRAIL $(20 \mathrm{ng} / \mathrm{ml} ; \mathrm{T} 20)$ for $24 \mathrm{~h}$ significantly increased the sub-G1 population (to $6.0 \pm 1.8 \%$ ) in LNCap cells compared to treatment with Vitisin A $(4 \mu \mathrm{M} ; 4.3 \pm 0.3 \%)$ or TRAIL ( $20 \mathrm{ng} / \mathrm{ml} ; 4.2 \pm 0.5 \%$ ) alone (Fig $2 \mathrm{G}$ and $\mathrm{H}$ ). Taken together, we found that combined treatment of Vitisin A ( $4 \mu \mathrm{M} ; \mathrm{V} 4)$ and TRAIL $(20 \mathrm{ng} / \mathrm{ml} ; \mathrm{T} 20)$ increased 


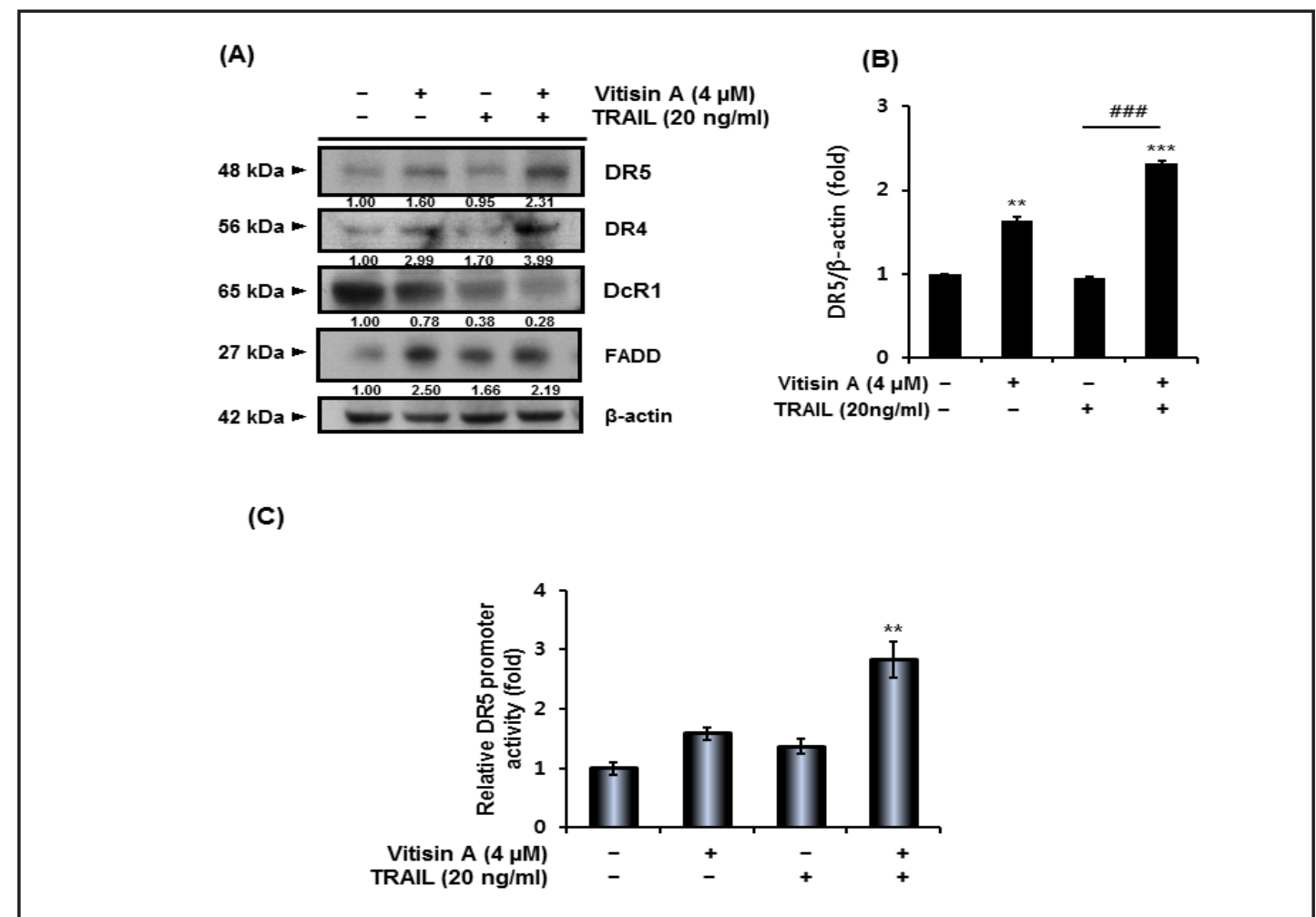

Fig. 4. Combined effect of Vitisin A and TRAIL on cell death proteins and DR5 expression in PC-3 prostate cancer cells. PC-3 cells were treated with Vitisin A $(4 \mu \mathrm{M})$ and/or TRAIL $(20 \mathrm{ng} / \mathrm{ml})$ for $24 \mathrm{~h}$. (A) Effect of Vitisin A and TRAIL on the death receptor-related proteins such as DR4, DR5, DcR1 and FADD in PC-3 cells, as determined by Western blotting. Whole cell extracts were lysed and analyzed by western blotting using antibodies against DR4, DR5, DcR1, FADD and $\beta$-actin. The values represent quantified bands of western blots analyzing by using Image J software. (B) The ratio of DR5/ $\beta$-actin was determined using the Image J software. (C) Effect of Vitisin A and TRAIL on DR5 promoter activity. DR5 promoter plasmid and Renilla luciferase were transfected into PC-3 cells. After $24 \mathrm{~h}$, Vitisin A ( $4 \mu \mathrm{M})$ and/or TRAIL $(20 \mathrm{ng} / \mathrm{ml})$ were added to PC-3 cells. Briefly, luciferase activity was normalized to that of Renilla luciferase and effect of Vitisin A and TRAIL was evaluated on DR5 promoter activity. Data are presented as means \pm SD of triplicate samples. ${ }^{* *}$ $\mathrm{p}<0.01$ vs untreated control.

sub G1 population in PC-3 cells $(28.7 \pm 0.4 \%)$ better than DU145(10.03 $\pm 0.2 \%)$ cells or LNCap $(6.0 \pm 1.8 \%)$ cells. Thus, next experiment was carried out mainly in PC-3 cells.

Combined treatment with Vitisin A and TRAIL regulated apoptosis-related proteins and DR5 in PC-3 prostate cancer cells

To determine whether Vitisin A and/or TRAIL affect apoptosis, we assessed the expression levels of pro-apoptotic and anti-apoptotic proteins by Western blotting. As shown in Fig. 3A and B, combined treatment with Vitisin A ( $4 \mu \mathrm{M})$ and TRAIL $(20 \mathrm{ng} / \mathrm{ml})$ increased the cleavage of PARP and caspase7/3 and attenuated the expression of pro-caspase $7 / 8$ but not pro-caspase 9 in PC-3 prostate cancer cells. Consistently, combined treatment with Vitisin A $(4 \mu \mathrm{M})$ and TRAIL $(20 \mathrm{ng} / \mathrm{ml})$ suppressed the expression of the anti-apoptotic proteins Bcl-2 and Bcl- ${ }_{\mathrm{XL}}$ in PC-3 prostate cancer cells compared to Vitisin A or TRAIL alone (Fig. 3B). Next, we examined the expression of TRAIL death receptors and its associated proteins such as DR4, DR5, FADD and Dcr1 by Western blotting. As shown in Fig. 4A and B, combined treatment with Vitisin A ( $4 \mu \mathrm{M})$ and TRAIL $(20 \mathrm{ng} / \mathrm{ml})$ synergistically upregulated DR4, and DR5 in PC-3 prostate cancer cells, and downregulated the expression of Dcr1, but not FADD compared to Vitisin A or TRAIL alone. However, here we focused on the role of DR5 in combination induced apoptosis in PC-3 cells. Thus, luciferase assay was performed KARGER 
(A)

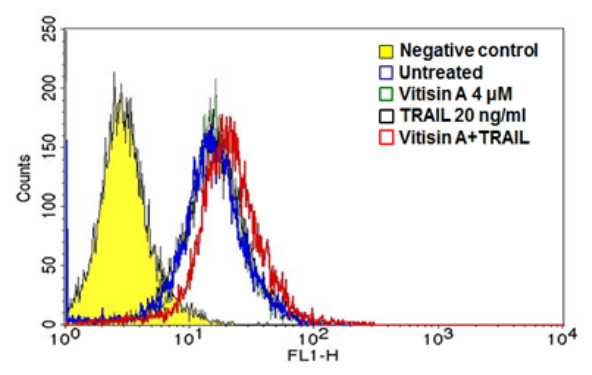

(B)

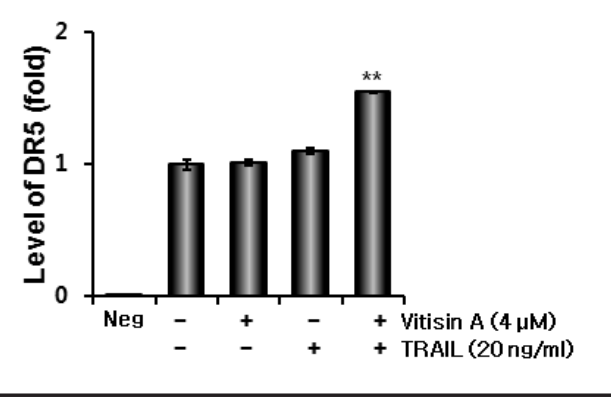

Fig. 5. Combined effect of Vitisin A and TRAIL on DR5 cell surface expression in PC-3 prostate cancer cells. (A) Surface DR 5 receptor level in Vitisin A $(4 \mu \mathrm{M})$ and/or TRAIL $(20 \mathrm{ng} / \mathrm{ml})$ treated PC-3 cells was determined by flow cytometry with using a FITC-conjugated anti-DR5 antibody and a control IgG (negative control). Histograms obtained in a representative experiment are shown. (B) Graph represents quantified fluorescence intensity for cell surface DR5 expression. ${ }^{* *} \mathrm{p}<0.01$ vs untreated con- $\beta$ trol. Data are presented as means \pm SD of triplicate samples.
(A)

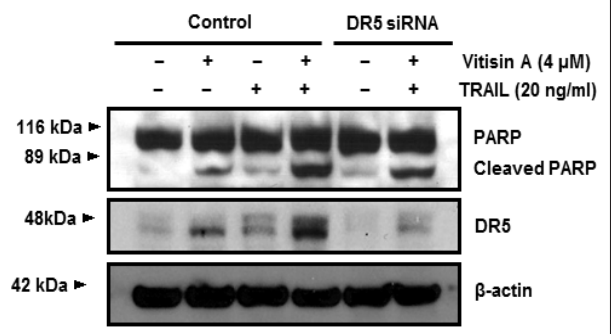

(B)

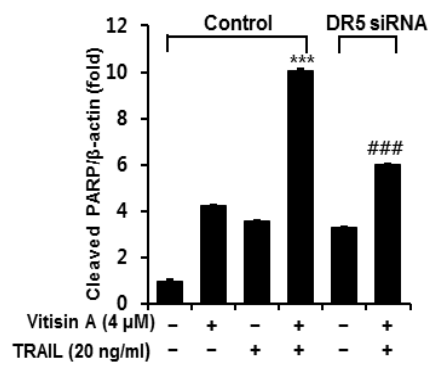

Fig. 6. Silencing of DR5 by transfection assay attenuates PARP cleavage in PC-3 cells treated with combination of Vitisin A and TRAIL. PC-3 cells were transfected with control or DR5 siRNA plasmids for $48 \mathrm{~h}$ and then treated with Vitisin $\mathrm{A}(4 \mu \mathrm{M})$ and/or TRAIL (20 ng/ml) for $24 \mathrm{~h}$. (A) Effect of siRNA DR5 transfection on PARP cleavage in PC-3 cells. Western blot was subjected to determine the levels of DR5, PARP, and $\beta$-actin. (B) Relative level of cleaved PARP/ $\beta$-actin was determined using the ImageJ software. Data are presented as means \pm SD of triplicate samples. ${ }^{* * *} \mathrm{p}<0.001 v s$. Vitisin A or TRAIL alone, \#\#\# $\mathrm{p}<0.001 \mathrm{vs}$. Vitisin A and TRAIL combined treatment.

for DR5 promoter activity. A pDR5/-605 promoter construct was transfected into PC-3 cells to determine DR5 activity. As shown in Fig. 4C, combined treatment of Vitisin A (4 $\mu \mathrm{M})$ and TRAIL ( $20 \mathrm{ng} / \mathrm{ml}$ ) for $24 \mathrm{~h}$ increased DR5 promoter activity in PC-3 cells compared to Vitisin A or TRAIL alone (Fig. 4C). To evaluate the cell surface expression of DR5, flow cytometry was used. Combined treatment of Vitisin A $(4 \mu \mathrm{M})$ and TRAIL $(20 \mathrm{ng} / \mathrm{ml})$ effectively moved histogram shift for cell surface expression of DR5 to right in PC-3 cells compared to Vitisin A or TRAIL alone (Fig. 5A, 5B). To investigate the role of DR5 in combined treatment of Vitisin A and TRAIL induced apoptosis, DR5 siRNA transfection assay was used. After transfection with control or DR5 siRNA plasmid in PC-3 cells, Vitisin A and/or TRAIL were added for $24 \mathrm{~h}$ in transfected PC-3 cells. Western blotting revealed that silencing of DR5 reduced the ability of combination of Vitisin A and TRAIL to induce PARP cleavage in PC-3 cells compared to untreated control (Fig. 6).

Combined effect of Vitisin A and TRAIL on ROS production in PC-3 prostate cancer cells

Vitisin A induced ROS production similar to $\mathrm{H}_{2} \mathrm{O}_{2}$ as a positive control, while ROS inhibitor NAC reduced ROS production in PC-3 cells by flow cytometric analysis (Fig. 7A KARGER 
(A)

(B)

(C)
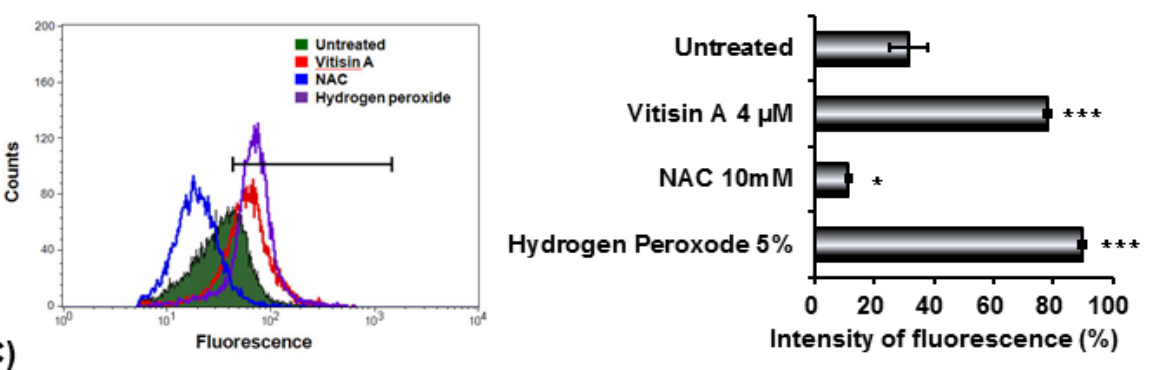

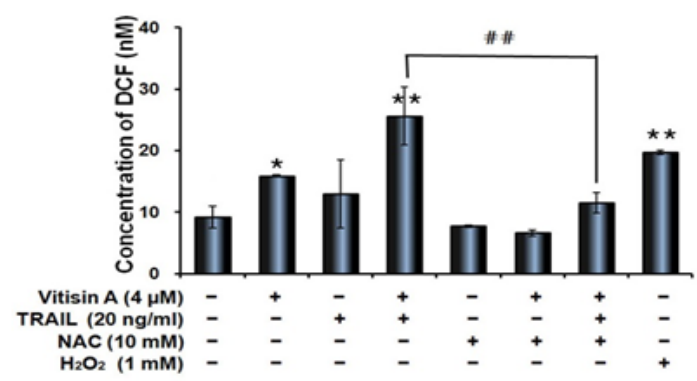

(D)

$$
\begin{array}{lllllll}
- & + & + & + & + & - \\
- & - & + & + & + & - & \operatorname{Titisin} A(4 \mu \mathrm{M}) \\
& & & & &
\end{array}
$$$$
-\quad+\quad+\quad+\quad+\quad N A C(10 \mathrm{mM})
$$

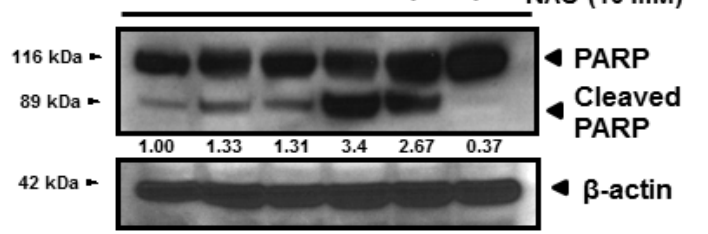

(E)

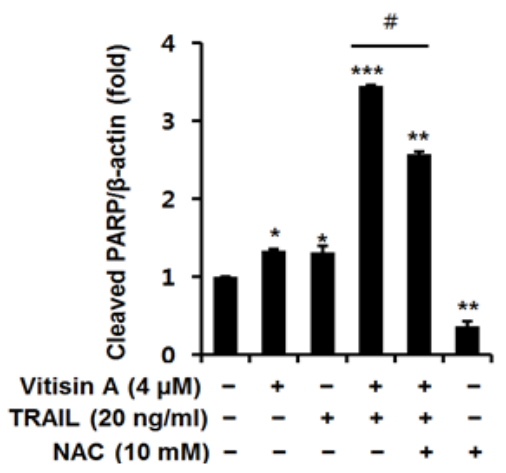

Fig. 7. Combined effect of Vitisin A and TRAIL on ROS production in PC-3 prostate cancer cells. (A) Representative histograms by treatment of Vitisin A $(4 \mu \mathrm{M})$, ROS inhibitor NAC $(10 \mathrm{mM})$ or $\mathrm{H}_{2} \mathrm{O}_{2}(1 \mathrm{mM})$ on ROS production in PC-3 cells. PC-3 cells were incubated with Vitisin A for $1 \mathrm{~h}$. ROS levels were determined by flow cytometric analysis. (B) Bar graphs represent the results of three independent experiments. Data are presented as means \pm SD of triplicate samples. ${ }^{*} \mathrm{p}<0.05$, ${ }^{* * *} \mathrm{p}<0.001$ vs untreated control. (C) Effects of Vitisin A $(4 \mu \mathrm{M})$ and TRAIL $(20 \mathrm{ng} / \mathrm{ml})$ cotreatment on ROS production in the absence or presence of NAC, as determined using a microplate fluorometer. Data are presented as means \pm SD of triplicate samples. ${ }^{*} \mathrm{p}<$ $0.05,{ }^{* *} \mathrm{p}<0.01$ vs. untreated control; \#\# $\mathrm{p}<0.01$ vs. treatment with Vitisin A or TRAIL. (D) Effect of NAC on PARP cleavage in Vitisin A and TRAIL treated PC-3 prostate cancer cells, as determined by Western blotting. (E) Relative level of cleaved PARP/ $\beta$-actin was determined using the Image J software. Data are presented as means \pm SD of triplicate samples. ${ }^{*} \mathrm{p}<0.05,{ }^{* *} \mathrm{p}<0.01,{ }^{* * *} \mathrm{p}<0.001$ vs untreated control; \# $\mathrm{p}<0.05$ vs Visitin A and TRAIL combined treatment.

and 7B). Combined treatment with Vitisin A ( $4 \mu \mathrm{M})$ and TRAIL (20 ng/ml) synergistically enhanced ROS production in PC-3 cells better than Vitisin A ( $4 \mu \mathrm{M})$ or TRAIL $(20 \mathrm{ng} / \mathrm{ml})$ or positive control $\mathrm{H}_{2} \mathrm{O}_{2}$ alone using a microplate fluorometer (Fig. 7C). However, ROS inhibitor NAC attenuated the ability of Vitisin A and TRAIL to induce ROS production in PC-3 cells (Fig. 7C). Consistently, NAC blocked the ability of Vitisin A and TRAIL to induce PARP cleavage in PC-3 cells as shown by Western blotting (Fig. 7D). 


\section{Cellular Physiology Cell Physiol Biochem 2015;36:1151-1162

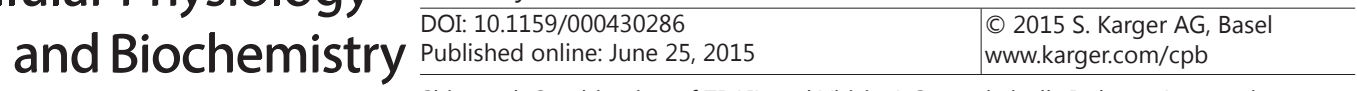 \\ Shin et al: Combination of TRAIL and Vitisin A Synergistically Induces Apoptosis}

\section{Discussion}

To assess the potential of Vitisin A as a sensitizer to TRAIL induced apoptosis in prostate cancer cells, current study was performed. Combination of Vitisin A and TRAIL enhanced cytotoxicity compared to Vitisin or TRAIL alone in PC-3 and DU145 prostate cancer cells, implying synergism between Vitisin A and TRAIL. In cell cycle analysis to check whether or not the cytotoxicity of the combination is due to apoptosis, combination of Vitisin A and TRAIL synergistically increased sub-G1 population in PC-3 and DU145 cells compared to Vitisin or TRAIL alone, indicating synergistic apoptotic effect by combination of Vitisin A and TRAIL.

In general, apoptosis, so-called programmed cell death, involves two typical caspasedependent pathways. One is intrinsic mitochondria-dependent apoptosis, in which cytochrome $\mathrm{c}$ is released and binds to apoptotic protease activating factor 1 (Apaf-1) and ATP, and then binds to pro-caspase 9 to create an apoptosome to finally activate the effector caspase 3 [22-24]. The other is extrinsic death receptor-dependent apoptosis. The Fas receptor binds Fas ligand (FasL), a transmembrane protein of the TNF family. Also, the deathinducing signaling complex (DISC), consisting of FADD, caspase 8 and caspase 10, directly activates the execution of apoptosis via caspase $3[23,25,26]$. In our study, combination of TRAIL and Vitisin A induced the cleavage of PARP and caspase 3, attenuated the expression of pro-caspase 7/8, and DcR1 but not pro-caspase 9, and activated DR4 and DR5 in PC-3 cells, implying death-receptor-dependent pathway by combination of TRAIL and Vitisin A.

There are accumulating evidences that DR5 upregulation is a promising molecular target for sensitizing tumor cells to TRAIL-induced apoptosis [27-29]. In the present study, combination of Vitisin A and TRAIL induced DR5 protein expression, significantly enhanced the activity of DR5 promoter and cell surface expression of DR5 in PC-3 cells. Conversely, silencing of DR5 by siRNA transfection also blocked the ability of Vitisin A to induce PARP cleavage in PC-3 cells, strongly demonstrating the important role of DR5 in apoptosis induction by combination of Vitisin A and TRAIL.

It is well documented that ROS plays a critical role in apoptosis induction in several cancers [30-33] and also ROS mediates TRAIL sensitization through modulation of TRAIL receptor DR5 in prostate cancer cells by several cancer chemopreventive agents such as Orlistat [34], Celastraol [35] and Baicalein [36]. Our flow cytometric analysis revealed that combination of TRAIL and Vitisin A increased the production of ROS and conversely ROS inhibitor NAC blocked the ability of combination of TRAIL and Vitisin A to cleave PARP in PC-3 cells, indicating the role of ROS in apoptotic effect by combination of TRAIL and Vitisin A. Our findings that combination of TRAIL and Vitisin A induces apoptosis as a potent TRAIL sensitizer are supported by previous evidences that resveratrol sensitized HepG2 [37], melanoma [38], neuroblastoma [39] and prostate cancer cells [40-42] to TRAIL induced apoptosis, since vitisin $\mathrm{A}$ is a complex of resveratrol dimers.

In summary, combined treatment with Vitisin A and TRAIL increased cytotoxicity and the sub-G1 population in PC-3, DU145 and LNCap prostate cancer cells, induced apoptosis by cleavage of PARP and caspase 3, inhibited pro-caspases 7/8, DcR1, and activated DR5 in PC-3 cells. Furthermore, the combination of TRAIL and Vitisin A increased the production of ROS. Conversely, ROS inhibitor NAC and silencing of DR5 by siRNA transfection blocked the ability of Vitisin A and TRAIL to induce PARP cleavage in PC-3 cells. These findings suggest that combination of TRAIL and Vitisin A synergistically induces apoptosis in prostate cancer cells via upregulation of DR5 and production of ROS as a potent TRAIL sensitizer.

\section{Acknowledgement}

This work was supported by a National Research Foundation of Korea (NRF) grant funded by the Korean government [MEST] (No. 2012-0005755).

\section{Disclosure Statement}

The authors have no conflicts of interest to disclose.

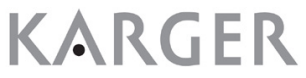




\section{Cellular Physiology Cell Physiol Biochem 2015;36:1151-1162 \begin{tabular}{l|l|l} 
DOI: 10.1159/000430286 & (C)15 S. Karger AG, Basel
\end{tabular}

\section{References}

Niraula S, Le LW, Tannock IF: Treatment of prostate cancer with intermittent versus continuous androgen deprivation: a systematic review of randomized trials. J Clin Oncol 2013;31:2029-2036.

2 Chen FZ, Zhao XK: Prostate Cancer: Current Treatment and Prevention Strategies. Iran Red Crescent Med J 2013;15:279-284.

3 Voortman J, Resende TP, Abou El Hassan MA, Giaccone G, Kruyt FA: TRAIL therapy in non-small cell lung cancer cells: sensitization to death receptor-mediated apoptosis by proteasome inhibitor bortezomib. Mol Cancer Ther 2007;6:2103-2112.

4 Mirandola P, Gobbi G, Sponzilli I, Malinverno C, Cavazzoni A, Alfieri R, Petronini PG, Vitale M: TRAILinduced apoptosis of FHIT-negative lung cancer cells is inhibited by FHIT re-expression. J Cell Physiol 2009;220:492-498.

5 Li G, Fu D, Liang W, Fan L, Chen K, Shan L, Hu S, Ma X, Zhou K, Cheng B: CYC1 silencing sensitizes osteosarcoma cells to TRAIL-induced apoptosis. Cell Physiol Biochem 2014;34:2070-2080.

6 Wu X, Yang N, Zhou WH, Xu J, Chen JJ, Zheng FM, Long ZJ, Yue CF, Ai KX, Liu LL, Wan XY, Liu Q: Up-regulation of P21 inhibits TRAIL-mediated extrinsic apoptosis, contributing resistance to SAHA in acute myeloid leukemia cells. Cell Physiol Biochem 2014;34:506-518.

7 Yerbes R, Palacios C, Lopez-Rivas A: The therapeutic potential of TRAIL receptor signalling in cancer cells. Clin Transl Oncol 2011;13:839-847.

8 Sallman DA, Chen X, Zhong B, Gilvary DL, Zhou J, Wei S, Djeu JY: Clusterin mediates TRAIL resistance in prostate tumor cells. Mol Cancer Ther 2007;6:2938-2947.

9 Voelkel-Johnson C, King DL, Norris JS: Resistance of prostate cancer cells to soluble TNF-related apoptosisinducing ligand (TRAIL/Apo2L) can be overcome by doxorubicin or adenoviral delivery of full-length TRAIL. Cancer Gene Ther 2002;9:164-172.

10 Mitterberger M, Neuwirt H, Cavarretta IT, Hobisch A, Culig Z: Increased resistance to trail-induced apoptosis in prostate cancer cells selected in the presence of bicalutamide. Prostate 2007;67:1194-1201.

11 Fandy TE, Srivastava RK: Trichostatin A sensitizes TRAIL-resistant myeloma cells by downregulation of the antiapoptotic Bcl-2 proteins. Cancer Chemother Pharmacol 2006;58:471-477.

12 Jung EM, Lim JH, Lee TJ, Park JW, Choi KS, Kwon TK: Curcumin sensitizes tumor necrosis factor-related apoptosis-inducing ligand (TRAIL)-induced apoptosis through reactive oxygen species-mediated upregulation of death receptor 5 (DR5). Carcinogenesis 2005;26:1905-1913.

13 Kim H, Kim EH, Eom YW, Kim WH, Kwon TK, Lee SJ, Choi KS: Sulforaphane sensitizes tumor necrosis factorrelated apoptosis-inducing ligand (TRAIL)-resistant hepatoma cells to TRAIL-induced apoptosis through reactive oxygen species-mediated up-regulation of DR5. Cancer Res 2006;66:1740-1750.

14 Kim JH, Park B, Gupta SC, Kannappan R, Sung B, Aggarwal BB: Zyflamend sensitizes tumor cells to TRAILinduced apoptosis through up-regulation of death receptors and down-regulation of survival proteins: role of ROS-dependent CCAAT/enhancer-binding protein-homologous protein pathway. Antioxid Redox Signal 2012;16:413-427.

15 Yadav VR, Prasad S, Aggarwal BB: Cardamonin sensitizes tumour cells to TRAIL through ROS- and CHOPmediated up-regulation of death receptors and down-regulation of survival proteins. Br J Pharmacol 2012;165:741-753.

16 Fulcrand H, Benabdeljalil C, Rigaud J, Cheynier V, Moutounet M: A new class of wine pigments generated by reaction between pyruvic acid and grape anthocyanins. Phytochemistry 1998;47:1401-1407.

17 Mi Jeong S, Davaatseren M, Kim W, Sung Kwang P, Kim SH, Haeng Jeon H, Myung Sunny K, Kim YS, Dae Young K: Vitisin A suppresses LPS-induced NO production by inhibiting ERK, p38, and NF-kappaB activation in RAW 264.7 cells. Int Immunopharmacol 2009;9:319-323.

18 Wu SS, Chen LG, Lin RJ, Lin SY, Lo YE, Liang YC: Cytotoxicity of (-)-vitisin B in human leukemia cells. Drug Chem Toxicol 2013;36:313-319.

19 Ong ET, Hwang TL, Huang YL, Lin CF, Wu WB: Vitisin B, a resveratrol tetramer, inhibits migration through inhibition of PDGF signaling and enhancement of cell adhesiveness in cultured vascular smooth muscle cells. Toxicol Appl Pharmacol 2011;256:198-208.

20 Kim SH, Park HS, Lee MS, Cho YJ, Kim YS, Hwang JT, Sung MJ, Kim MS, Kwon DY: Vitisin A inhibits adipocyte differentiation through cell cycle arrest in 3T3-L1 cells. Biochem Biophys Res Commun 2008;372:108-113.

21 Huang YL, Loke SH, Hsu CC, Chiou WF: (+)-Vitisin A inhibits influenza A virus-induced RANTES production in A549 alveolar epithelial cells through interference with Akt and STAT1 phosphorylation. Planta Med 


\section{Cellular Physiology Cell Physiol Biochem 2015;36:1151-1162 \begin{tabular}{l|l|l}
\hline DOI: $10.1159 / 000430286$ & (C) 2015 S. Karger AG, Basel
\end{tabular}

2008;74:156-162.

22 Elmore S: Apoptosis: a review of programmed cell death. Toxicol Pathol 2007;35:495-516.

23 Johnson MI, Hamdy FC: Apoptosis regulating genes in prostate cancer (review). Oncol Rep 1998;5:553-557.

24 Kanduc D, Mittelman A, Serpico R, Sinigaglia E, Sinha AA, Natale C, Santacroce R, Di Corcia MG, Lucchese A, Dini L, Pani P, Santacroce S, Simone S, Bucci R, Farber E: Cell death: apoptosis versus necrosis (review). Int J Oncol 2002;21:165-170.

25 Sheard MA: Apoptosis update: to be, or not to be, and how to arrange the latter. Meeting review. Neoplasma 1997;44:202-204.

26 Vicencio JM, Galluzzi L, Tajeddine N, Ortiz C, Criollo A, Tasdemir E, Morselli E, Ben Younes A, Maiuri MC, Lavandero S, Kroemer G: Senescence, apoptosis or autophagy? When a damaged cell must decide its path-a mini-review. Gerontology 2008;54:92-99.

27 Kim YH, Jung EM, Lee TJ, Kim SH, Choi YH, Park JW, Park JW, Choi KS, Kwon TK: Rosiglitazone promotes tumor necrosis factor-related apoptosis-inducing ligand-induced apoptosis by reactive oxygen speciesmediated up-regulation of death receptor 5 and down-regulation of c-FLIP. Free Radic Biol Med 2008;44:1055-1068.

28 Lim JH, Park JW, Choi KS, Park YB, Kwon TK: Rottlerin induces apoptosis via death receptor 5 (DR5) upregulation through CHOP-dependent and PKC delta-independent mechanism in human malignant tumor cells. Carcinogenesis 2009;30:729-736.

29 Jung EM, Park JW, Choi KS, Park JW, Lee HI, Lee KS, Kwon TK: Curcumin sensitizes tumor necrosis factor-related apoptosis-inducing ligand (TRAIL)-mediated apoptosis through CHOP-independent DR5 upregulation. Carcinogenesis 2006;27:2008-2017.

30 Zhong YY, Chen HP, Tan BZ, Yu HH, Huang XS: Triptolide avoids cisplatin resistance and induces apoptosis via the reactive oxygen species/nuclear factor-kappaB pathway in SKOV3 platinum-resistant human ovarian cancer cells. Oncol Lett 2013;6:1084-1092.

31 Xu L, Feng JM, Li JX, Zhu JM, Song SS, Tong LJ, Chen Y, Yang XY, Shen YY, Lian FL, Li YP, Lin DH, Ding J, Miao ZH: Tanshinone-1 induces tumor cell killing, enhanced by inhibition of secondary activation of signaling networks. Cell Death Dis 2013;4:e905.

32 Stojnev S, Ristic-Petrovic A, Jankovic-Velickovic L: Reactive oxygen species, apoptosis and cancer. Vojnosanit Pregl 2013;70:675-678.

33 Jeong JB, Choi J, Baek SJ, Lee SH: Reactive oxygen species mediate tolfenamic acid-induced apoptosis in human colorectal cancer cells. Arch Biochem Biophys 2013;537:168-175.

34 Fujiwara J, Sowa Y, Horinaka M, Koyama M, Wakada M, Miki T, Sakai T: The anti-obesity drug orlistat promotes sensitivity to TRAIL by two different pathways in hormone-refractory prostate cancer cells. Int J Oncol 2012;40:1483-1491.

35 Sung B, Park B, Yadav VR, Aggarwal BB: Celastrol, a triterpene, enhances TRAIL-induced apoptosis through the down-regulation of cell survival proteins and up-regulation of death receptors. J Biol Chem 2010;285:11498-11507.

36 Taniguchi H, Yoshida T, Horinaka M, Yasuda T, Goda AE, Konishi M, Wakada M, Kataoka K, Yoshikawa T, Sakai T: Baicalein overcomes tumor necrosis factor-related apoptosis-inducing ligand resistance via two different cell-specific pathways in cancer cells but not in normal cells. Cancer Res 2008;68:8918-8927.

37 Tameda M, Sugimoto K, Shiraki K, Inagaki Y, Ogura S, Kasai C, Yoneda M, Okamoto R, Yamamoto N, Takei Y, Ito M, Nobori T: Resveratrol sensitizes HepG2 cells to TRAIL-induced apoptosis. Anticancer Drugs 2014;10.1097/CAD.0000000000000128

38 Ivanov VN, Partridge MA, Johnson GE, Huang SX, Zhou H, Hei TK: Resveratrol sensitizes melanomas to TRAIL through modulation of antiapoptotic gene expression. Exp Cell Res 2008;314:1163-1176.

39 Fulda S, Debatin KM: Resveratrol-mediated sensitisation to TRAIL-induced apoptosis depends on death receptor and mitochondrial signalling. Eur J Cancer 2005;41:786-798.

40 Shankar S, Chen Q Siddiqui I, Sarva K, Srivastava RK: Sensitization of TRAIL-resistant LNCaP cells by resveratrol (3, 4', 5 tri-hydroxystilbene): molecular mechanisms and therapeutic potential. J Mol Signal 2007;2:7.

41 Horndasch M, Culig Z: SOCS-3 antagonizes pro-apoptotic effects of TRAIL and resveratrol in prostate cancer cells. Prostate 2011;71:1357-1366.

42 Ganapathy S, Chen Q Singh KP, Shankar S, Srivastava RK: Resveratrol enhances antitumor activity of TRAIL in prostate cancer xenografts through activation of FOXO transcription factor. PLoS One 2010;5:e15627. 